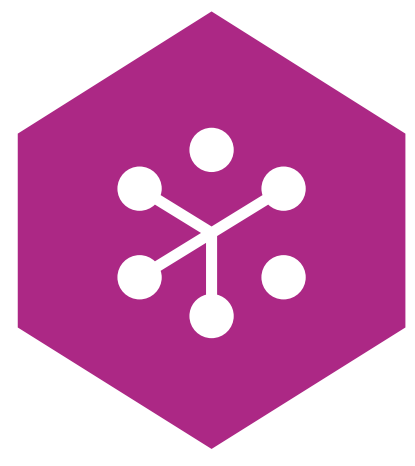

The International Journal of

Interdisciplinary

Educational Studies

Mentorship and Class Size

Approach to Building Self-Confidence for Rural

Preservice Teachers 


\section{EDITOR}

Marcin Galent, Jagiellonian University, Poland

ACTING DIRECTOR OF PUBLISHING

Jeremy Boehme, Common Ground Research Networks, USA

\section{MANAGING EDITOR}

Megan Donnan, Common Ground Research Networks, USA

\section{ADVISORY BOARD}

The Interdisciplinary Social Sciences Research Network recognizes the contribution of many in the evolution of the Research Network. The principal role of the Advisory Board has been, and is, to drive the overall intellectual direction of the Research Network. A full list of members can be found at https://thesocialsciences.com/about/advisory-board.

\section{PEER REVIEW}

Articles published in The International Journal of Interdisciplinary Educational Studies are peer reviewed using a two-way anonymous peer review model. Reviewers are active participants of The Interdisciplinary Social Sciences Research Network or a thematically related Research Network. The publisher, editors, reviewers, and authors all agree upon the following standards of expected ethical behavior, which are based on the Committee on Publication Ethics (COPE) Core Practices. More information can be found at: https://thesocialsciences.com/journals/model.

\section{ARTICLE SUBMISSION}

The International Journal of Interdisciplinary Educational Studies publishes biannually (June, December). For more about the submission process, please visit https://thesocialsciences.com/journals/call-for-papers.

\section{THE INTERNATIONAL JOURNAL OF}

\section{INTERDISCIPLINARY EDUCATIONAL STUDIES}

https://thesocialsciences.com

ISSN: 2327-011X (Print)

ISSN: 2327-2570 (Online)

https://doi.org/10.18848/2327-011X/CGP (Journal)

First published by Common Ground Research Networks in 2021 University of Illinois Research Park

60 Hazelwood Drive

Champaign, IL 61820 USA

$\mathrm{Ph}:+1-217-328-0405$

https://cgnetworks.org

\section{The International Journal of Interdisciplinary}

Educational Studies is a peer-reviewed, scholarly journal.

\section{COPYRIGHT}

(C) 2021 (individual papers), the author(s)

(C) 2021 (selection and editorial matter),

Common Ground Research Networks

All rights reserved. Apart from fair dealing for the purposes of study, research, criticism, or review, as permitted under the applicable copyright legislation, no part of this work may be reproduced by any process without written permission from the publisher. For permissions and other inquiries, please contact cgscholar.com/cg_support.

\section{Crossref}

Common Ground Research Networks, a member of Crossref

\section{ABSTRACTING AND INDEXING}

For a full list of databases in which this journal is indexed, please visit https://thesocialsciences.com/journals/collection.

\section{RESEARCH NETWORK MEMBERSHIP}

Authors in The International Journal of Interdisciplinary Educational Studies are members of the Interdisciplinary Social Sciences Research Network or a thematically related Research Network. Members receive access to journal content. To find out more, visit https://thesocialsciences.com/about/become-a-member.

\section{SUBSCRIPTIONS}

The International Journal of Interdisciplinary Educational Studies is available in electronic and print formats. Subscribe to gain access to content from the current year and the entire backlist. Contact us at cgscholar.com/cg support.

\section{ORDERING}

Single articles and issues are available from the journal bookstore at https://cgscholar.com/bookstore.

\section{HYBRID OPEN ACCESS}

The International Journal of Interdisciplinary Educational Studies is Hybrid Open Access, meaning authors can choose to make their articles open access. This allows their work to reach an even wider audience, broadening the dissemination of their research. To find out more, please visit https://thesocialsciences.com/journals/hybrid-open-access.

\section{DISCLAIMER}

The authors, editors, and publisher will not accept any legal responsibility for any errors or omissions that may have been made in this publication. The publisher makes no warranty, express or implied, with respect to the material contained herein. 


\title{
Mentorship and Class Size: Approach to Building Self-Confidence for Rural Preservice Teachers
}

\author{
Chinaza Uleanya, ${ }^{1}$ University of South Africa, South Africa
}

\begin{abstract}
Self-confidence is a vital trait that teachers are expected to possess before venturing into the teaching profession or going into a class to teach. The issue of self-confidence of teachers is considered to be predicated on different factors. This research study explored the connection between support from subject mentors to preservice teachers, class sizes taught by student teachers, and their self-confidence. A qualitative method was adopted for data collection from the six selected preservice teachers undergoing teaching practice in three carefully selected high schools in KwaZulu-Natal Province of South Africa. The finding of the study shows that large class sizes mostly affect the self-confidence of preservice teachers negatively. Also, the role played by subject mentors in boosting the self-confidence of preservice teachers is immense and cannot be overemphasised. Thus, the study recommends, among other things, that preservice teachers should first be exposed to small class sizes to aid their self-confidence before being exposed to large class sizes. Meanwhile, subject mentors should be given periodic workshops on the things expected of them during teaching practice exercises and they should be motivated through various means to mentor preservice teachers.
\end{abstract}

Keywords: Class Sizes, High School, Self-Confidence, Student Teachers, Preservice Teacher, Subject Mentor

\section{Introduction}

$\mathrm{T}$ leachers are sometimes considered as sages who ought to know everything about what they teach and do. In some instances, any form of negligence on their part is considered tantamount to malpractice and expected to be treated as such (Hutt and Tang 2013; Uleanya and Gamede 2018). A review of the work of Hutt and Tang (2013) suggests that schools are established to ensure the transfer of knowledge and skills to students; however, when they fail in their responsibility of doing so, they are considered as being negligent, and Sometimes construed as some form of malpractices (Uleanya and Gamede 2018). By extension, a teacher who fails to fulfill the need for which he or she was recruited is to be considered as negligent and is to be viewed as being involved in malpractice. In order for such acts of negligence or malpractices to be avoided by teachers, several factors are to be duly taken into consideration and handled well. For instance, according to Sibiya, Gamede, and Uleanya (2019), classroom management is an important factor to be considered. Uleanya and Gamede (2018) opine that the teaching strategies adopted are crucial in this regard, while Uleanya, Rugbeer, and Olaniran (2019) consider the language of instruction as a major factor. Conversely, all the identified factors remain ineffective without some degree of self-confidence in the teacher, a preservice teacher, in the case of this studypreservice. Suffice it to state that self-confidence must be considered a vital factor which is to be nurtured with caution, especially with preservice teachers. According to Baumeister et al. (2003), Baker, Grant, and Morlock (2008), as well as Shore (2016), self-confidence is a product of various elements. In the case of preservice teachers who are students, though they are teachers in the making, factors such as how they relate with their own teachers-who in this case are their mentors-is important (Baumeister et al. 2003; Shore 2016; Uleanya and Gamede 2018). According to Uleanya and Gamede (2018), it is believed that student-teachers can easily overcome their challenges in learning and adapting to their new environment when they have the support of their teachers, who are referred to as subject mentors. But in reality, in many instances, subject

\footnotetext{
${ }^{1}$ Corresponding Author: Chinaza Uleanya, Floor 4 Nkoana Simon Radipere Building, Preller St., Pretoria, Business Management Department, University of South Africa, Gauteng, 0002, South Africa. email: chinazauleanya@yahoo.com
}

The International Journal of Interdisciplinary Educational Studies

Volume 16, Issue 2, 2021, https://thesocialsciences.com

(C) Common Ground Research Networks, Chinaza Uleanya, All Rights Reserved.

Permissions: cgscholar.com/cg support

ISSN: 2327-011X (Print), ISSN: 2327-2570 (Online)

https://doi.org/10.18848/2327-011X/CGP/v16i02/1-9 (Article) 
mentors are just happy to receive student-teachers and assign their normal teaching tasks to them, providing them with little or no support. The research based on observation notes that some subject mentors feel relieved during the period of teaching practice, which they believe is a time for them to relax from their regular daily teaching duties, while some amateurs are left to do the work.

Self-confidence remains a phenomenon which affects both preservice and professional teachers in various ways (Valazza 2019). Hence, teachers must undergo different forms of exercises in order to enhance their self-confidence, which is no doubt a vital quality to possess during teaching and learning activities. The common notion is that all teachers are individuals with a lot of confidence who are bold and can express themselves on different subject matters. Different scholars such as Bruno and Njoku (2014), Jan (2015), Omodan and Dube (2020), among others, have explored the various factors capable of affecting the self-confidence of teachers. On reviewing the work of these identified scholars, the factors hampering the selfconfidence of teachers can be categorized into personal and institution-based factors. Personal factors include a lack of faith in themselves and their abilities, while institutional factors comprise a lack of empowerment through relevant trainings and a lack of necessary support materials, among others. The existing research however, has mainly focused on professional teachers, and not on preservice teachers. It has also failed to explore the role of mentorship and class size in aiding the self-confidence of teachers. Hence, this study aims at exploring how the self-confidence of preservice teachers can be built through factors like classroom size and relationship with subject mentors.

Furthermore, Valazza (2019) reports that there is an interconnectedness between the selfconfidence of a teacher, his or her teaching abilities, and the knowledge that he or she possesses. In other words, a teacher who possesses good teaching abilities and has sound knowledge of what to teach is likely to display good levels of self-confidence. This implies that the self-confidence of a teacher can be dampened when there is a lack of knowledge on the content of the lesson or subject matter to be taught. However, good knowledge of what is to be taught, without adequate teaching abilities also tends to lead to a lack of self-confidence; the other side of the same coin is that a lack of self-confidence can lead to poor teaching, though the teacher possesses the knowledge of what is to be taught. This is represented using a simple equation, as shown below:

Knowledge of content - teaching ability $=$ Lack of self-confidence

Lack of self-confidence + Knowledge of content $=$ Poor teaching ability

Teaching ability - Self-confidence + Knowledge of content $=$ Poor output

The above equations suggest that self-confidence, knowledge of content, and teaching abilities are intertwined, and all three are to be possessed by teachers. This suggests that self-confidence is paramount for teachers in the pursuit of success in the teaching profession. Valazza (2019) further suggests ways by which teachers can develop their confidence, improve their teaching abilities, and become better in their chosen profession. Developing their knowledge of the subject matter(s), getting a deeper understanding of the different theories underpinning learning and teaching practices, getting to know their learners, and understanding their work environment are various ways by which teachers can build their self-confidence in relation to their profession and become better teachers (Valazza 2019). However, while Valazza (2019) explored the importance of self-confidence, the impact of knowledge about what to teach, and the role of teaching ability, the study did not explore the impact of class size and mentorship in aiding preservice teachers' building of self-confidence. Another scholar, Herbert-Smith (2018), identifies the following six strategies by which teachers can build self-confidence: 
- Teachers must be prepared. In this regard, they are to have knowledge of what is to be taught, how they intend to go about the lesson, and make all needed items readily available.

- They must be able to be properly poised while in class. In other words, teachers are to learn to walk tall. By so doing, they ensure that they are in control of their class.

- The classroom is to be governed and guided by rules stipulated by the teacher. The rules are to be adhered to strictly to ensure discipline. Herbert-Smith adds that the teacher is to be calm about happenings in class in spite of the rules, in order not to lose control out of anger or frustration. She further states that standing still when learners try to be rowdy and noisy can help the teacher to remain calm without getting frustrated, while waiting for learners to eventually become orderly.

- Avoidance of fear of criticism is important. According to Herbert-Smith (2018), teachers are to ensure that they remain fearless in the midst of criticism, rather they can use such criticism to their advantage.

- Avoidance of anger and being ever-complaining is crucial as well. Herbert-Smith (2018) holds the view that when teachers face challenges, continuous reflection on these and complaints over such issues without actions will not resolve them. Hence, in order to build confidence, teachers are to strive to not constantly complain about everything without making efforts to resolve their challenges.

- Constant reflection on one's own practices in order to emphasize one's strengths is considered important and necessary. Thus, Herbert-Smith (2018) recommends that teachers are to reflect on their practice in a conscious attempt to realize their strengths, which can be eventually channeled towards overcoming challenges and achieving success in their chosen profession.

A review of the six cogent strategies itemized by Herbert-Smith (2018) towards building selfconfidence by teachers suggests that teachers have different roles to play in ensuring that they are self-confident while discharging their duties. However, this study also failed to investigate the role of class size and mentorship in helping preservice teachers build self-confidence.

Class size is a major factor which affects teaching and learning activities. Yelkpieri et al. (2012) state that large class size is one of the major problems in the education sector in underdeveloped and developing societies, one of which is South Africa. Aoumeur (2017) opines that large class size adversely affects the learning abilities of students, especially when the available resources are not commensurate with the number of learners. This implies that large class size is considerably common in underdeveloped and developing nations and that students are affected negatively by large class sizes. According to Osborne (2018), teachers are also affected by large class sizes. Blatchford et al. (2002), as well as Osborne (2018) hold the view that the self-confidence of teachers is affected negatively when teaching large classes. Blatchford et al. (2002) further state that large class sizes hamper the teaching abilities of teachers. Suffice it to state that the teaching abilities and self-confidence of preservice teachers are likely to be negatively affected when they are faced with large class sizes.

Thus, considering that preservice teachers are yet to become experts, they need all the possible support, such as provision of necessary teaching and learning support materials, exposure to teaching strategies, among others, to enable them to thrive in the teaching profession. However, if there is an absence of self-confidence, regardless of the provision of the necessary supports, it would be a wasted effort, because of the large impact that the selfconfidence of teachers plays in ensuring that outlined objectives and goals are achieved. In most cases, preservice teachers are provided just basic materials and platforms to teach, regardless of the class size. In some instances, they are left without mentors, who are expected to oversee their activities in class, and guide and correct them where necessary. This act seems to affect their levels of self-confidence while undergoing their training as preservice teachers. Hence, 
this study was undertaken, which explores the effect of class sizes and mentorship in building the self-confidence of preservice teachers in South Africa with emphasis on rural communities.

\section{Conceptualization of Terminology}

The abbreviation "PTR" is adopted in the study and used to mean "Preservice teachers response." This is done in an attempt to ensure that the names of participants are not mentioned. It aids anonymity, which is highly recommended for ethical reasons in research.

\section{Methodology}

The study explored the connection between class size, subject mentors, and the self-confidence of preservice teachers. A qualitative method was adopted through the use of semi-structured interviews. Kumar (2014), Creswell (2014), as well as Du Plooy-Cilliers, Davis, and Bezuidenhout (2014) advocate the use of qualitative methods in studies in order to get in-depth information about a subject. The sample of the study comprised six selected preservice teachers undergoing teaching practice in three carefully selected high schools in KwaZulu-Natal Province of South Africa. The six selected preservice teachers were registered students of a rural university in South Africa at the time of data collection. They preservice were selected considering certain factors, which include: their schedule, availability, interest to take part in the study, willingness to disclose information about their experiences in the school where they were undergoing their teaching practice exercise, class sizes taught, and availability or nonavailability of subject mentors. On the other hand, the high schools were deliberately selected based on certain characteristics, as the researcher attempted to ensure that the schools had similar features. These characteristics include school size, class sizes, number of learners, location of schools, source of funding, and availability of preservice teachers, among others. The collected data were coded, and thereafter analyzed using themes.

\section{Instrument}

Semi-structured interviews were conducted with the six selected preservice teachers in order to elicit in-depth information from them for the study. As mentioned earlier, these preservice teachers were selected based on their time, schedule, availability, and interest to participate in the study. The items of the semi-structured interviews aimed at retrieving information on the following areas: involvement and influence of subject mentors, class size and their abilities to take charge, and the knowledge of preservice teachers on the teaching subjects. The responses retrieved through the semi-structured interviews were used to provide answers to the identified research questions guiding the study. The interview schedule guide comprised various questions which were targeted at procuring answers related to the following predefined themes: influence of relationship between subject mentor and preservice teacher, link between class size and preservice teachers' self-confidence, link between the knowledge of lessons as well as subject(s) taught by preservice teachers and their self-confidence.

\section{Results}

The results of the analyzed data are presented in this section, along with the demographic profile of the participants. 
FIRST AUTHOR LAST NAME: ARTICLE TITLE

Table 1: The Demographic Profile of Participants (Pre-Service Teachers)

\begin{tabular}{|l|c|c|c|}
\hline Gender & $\begin{array}{c}\text { Frequency } \\
(N=6)\end{array}$ & $\begin{array}{c}\text { Level of } \\
\text { Study }\end{array}$ & Percent \\
\hline Male & 3 & 3 & 50.0 \\
\hline Female & 3 & 3 & 50.0 \\
\hline Total & 6 & 6 & 100.0 \\
\hline \multicolumn{4}{|c|}{ Source: Uleanya }
\end{tabular}

Table 1 indicates that there were six participants in the study, three male and three female, thus ensuring representation of both genders in the study. The table also indicates that the participants were in Level 3 of their studies at the point when the study was conducted, as preservice teaching practice usually takes place when students are in their third year of study.

The findings of the study are presented under three broad themes: 1) influence of relationship between subject mentor and preservice teacher; 2) class size-cum-preservice teachers' self-esteem; and 3) link between knowledge of lessons as well as subject(s) taught by pre-service teachers and their self-confidence.

\section{Theme 1: Influence of Relationship between Subject Mentor and Preservice Teacher}

The findings on this theme indicate that while some subject mentors assist the preservice teachers by going to class with them, others fail to do so. The study also shows that preservice teachers whose subject mentors go to class with them tend to get support and are duly prepared for any form of evaluation or teaching. For instance, one of the participants stated: "My subject mentor goes to class with me regularly and this has helped me. I am ready for evaluation" PTR1. Another participant reported: "I relate well with my subject mentor. He's really helping me. I am ready for the tasks" PTR6.

The responses from the identified participants suggest that preservice teachers tend to be duly prepared for teaching when they get the assistance of their subject mentor. This finding corroborates the work of Uleanya and Gamede (2018) who state that a student-teacher relationship builds the self-confidence of the students. In this study, the relationship between the preservice teachers (the students) and their mentors (the teachers) helps to boost the selfconfidence of the preservice teachers.

The converse finding also corroborates with this, where students without the support of their subject mentors tend to be disadvantaged. For instance, one of the participants reported: "My subject mentor is not around; he's attending a workshop. ...It's not interesting going to class without him. The learners just do whatever they like when I'm in class alone" PTR2. The report of another participant states: "I am yet to get the necessary materials from my subject mentor, so I don't think I can afford to go to class to be supervised anytime soon" PTR4.

This finding coincides with the work of Bruno and Njoku (2014) whose work reflects that the role of subject mentors in assisting preservice teachers is undeniable in building their selfconfidence. Thus, where the subject mentors are not available, preservice teachers tend to lack confidence. Additionally, a participant stated that: "We are not allowed to teach for now, we are still observing. We will only start teaching when our subject mentor considers us fit and asks us to do so" PTR3.

These findings preservice show that the relationship that exists between student teachers and their subject mentors has the potential to boost their levels of confidence. Baker, Grant, and Morlock (2008), Shore (2016), and Uleanya and Gamede (2018) emphasize the need for a cordial relationship between students and teachers in order to build the self- confidence of the students. Suffice it to state that where there is a good and cordial relationship between the preservice teachers (students) and their subject mentors (teachers), the self-confidence of the 
preservice teachers with regard to teaching will be developed. Bruno and Njoku (2014) also hold the view that the role of teachers - in this regard, subject mentors - is very important in helping their students (preservice teachers) to build self-confidence in order to become better and professional teachers.

\section{Class Size-Cum-Preservice Teachers'Self-Confidence}

The findings from the analyzed data on the theme related to the link between class size and the self-confidence of preservice teachers show that preservice teachers with fewer students tend to display more confidence compared to others with large class sizes. For instance, a participant reported: "The class size contributes to my level of confidence. The learners that I teach are too many in class, over 70 of them. It doesn't help matters at all" PTR5. Two other participants agreed, saying: "I am happy that I had to teach a small class size. It really helped in building my self-confidence. This is how a class should be, not too many learners, at most 35 in a class" PTR2. "Teaching a small class made my job easy, interesting, and fine. I wonder what I would have done with my low voice if I was to teach a large class" PTR4. These findings show that a large class size is problematic and hampers the self-confidence of preservice teachers. This finding aligns with the work of Aoumeur (2017), who opines that preservice teachers display more confidence in a small class, compared to when they are given large classes. Like another participant says: "I believe that I will have more confidence and perform better than I'm doing now if I was to teach a small class. These learners are just too many for me to manage. I'm trying my best anyway" PTR1.

This finding of the study shows that class size contributes to building or damaging the selfconfidence of student teachers. This coincides with the findings of Yelkpieri et al. (2012) who state that large class size is a major challenge to the education sector in underdeveloped and developing nations, including South Africa. The finding also corroborates that of the works of Blatchford et al. (2002) and Osborne (2018) who state that the self-confidence and teaching abilities of teachers are negatively affected due to large class sizes. This finding implies that small classes have more advantages compared to classes with a huge population, as revealed by the work of Aoumeur (2017). Suffice it to state that the lesser the class population, the more impactful the teacher and teaching activities. The impact of teachers in such small class size situations may be predicated on the level of confidence possessed considering the scenario. In the same vein, if preservice teachers, who are not yet professionals, are given the opportunities to deal with small class sizes, they are likely to be more confident and impactful. This leads us to the third theme from the data analyzed, namely knowledge of lessons and subject(s) taught.

\section{Link between Knowledge of Lessons, Subject Taught and Self-Confidence of Preservice}

The findings of the study on the third theme show that the self-confidence of preservice teachers can be hampered or boosted by the level of knowledge possessed in the lessons and subject(s) taught. For instance, the report of one of the participants says: "Self-confidence of student teachers is not only about the class size or support of our subject mentors. I believe that our knowledge of the subject we teach contributes also to it. I can discuss with my learners well once I know what I'm to teach" PTR2. This finding shows that preservice teachers can boldly teach as long as they have the content knowledge of what is to be taught. The finding coincides with the work of Valazza (2019) who holds the view that the self-confidence of preservice teachers is positively influenced and boosted when they have knowledge of the content of what is to be taught. Another participant supports this by saying: "I believe that the subject taught has impact on our level of confidence as student teachers. For me, I have more confidence teaching history than geography. When I teach history, no matter the class size, presence, or absence of my subject mentor, I'll definitely do well" PTR3. Other participants, in support of the idea that 
the self-confidence of preservice teachers is largely dependent on their knowledge of the lesson and subject say the following: "The subject we teach and the level of knowledge we have in that subject helps to determine our level of self-confidence when teaching" PTR1. "I wish I was to be graded in only one subject, that way, I know that I'll perform better than I have done because I know the subject in which I'm better and have more confidence teaching" PTR6.

This finding of the study shows that the knowledge of the content of the lessons and subject(s) to be taught is a contributory factor to building the self-confidence of student teachers. This finding corroborates the findings of Sadler (2013), who holds the view that as nonprofessional teachers gather experience in the teaching profession and get to understand the content of what they teach better, their level of self-confidence increases. Valazza (2019) also concurs with the idea that knowing the content of what is to be taught has the potential to increase the self-confidence of preservice teachers. Valazza however, added that factors such as knowing the learners, understanding theories about learning and teaching, as well as the workplace environment contribute toward enhancing the self-confidence of preservice teachers as well.

\section{Conclusion and Recommendations}

This article explored the link between mentorship, class size, and the building of the selfconfidence of preservice teachers. Six selected preservice teachers studying in a rural university in South Africa were used as participants in this study. The findings of the study show that large class sizes negatively affect the self-confidence of preservice teachers. Hence, many of the preservice teachers prefer to be exposed to small class sizes compared to larger class sizes. This is based on preservice teachers' reports that their self-confidence increased due to their exposure to small class sizes. Additionally, the study also shows that the role of subject mentors is important in building the self-confidence of preservice teachers. This follows the finding that preservice teachers who had support from their subject mentors performed better compared to those who lacked the support of their subject mentors. Also, the analyzed data from the study indicates that besides the issue of mentorship and class size, preservice teachers' knowledge of the content of the lessons and subject(s) to be taught is an important factor that affects their selfconfidence. Subsequent to the findings of this study, the following recommendations are made:

1. Preservice teachers should be given a limited number of students to teach. The United Nations' Educational, Scientific, and Cultural Organization (UNESCO) standard of one teacher to thirty learners should be adhered to strictly. This will give them the opportunity to be exposed to and conveniently handle fewer learners while their esteem is being built.

2. Subject mentors should be encouraged to assist preservice teachers in building selfconfidence to teach. This can be done through an exclusive visit by a delegate representing the university to specifically interact with the subject mentors in schools with or without the knowledge of the preservice teachers.

3. Workshops should be organized periodically for subject mentors on things expected of them during teaching practice exercise and the need to duly mentor preservice teachers, as this could be categorized as service to the nation.

4. Subject mentors should be motivated through various means to adequately mentor preservice teachers. This can be done through issuance of prizes to the best-rated subject mentor in different schools following the performance of their mentees.

5. Preservice teachers should be taught to learn to adapt to any classroom situation with or without the aid of subject mentors. In this way, preservice teachers will learn to be independent during the teaching practice and this will help them in building their selfconfidence even when there are no available subject mentors. 
6. Preservice teachers should be encouraged and motivated to know the content of what is to be taught before they embark on any teaching and learning exercise. By doing so, they will not misinform the learners. Equally important, they will be confident of themselves when imparting any information in connection to the subject matter. This can be done through a one-to-one session with their subject mentors who will assist them in appropriately knowing the content of the lessons and subject(s) to be taught.

It is to be noted that the study was limited to only one selected province in South Africa. Hence, it is suggested that similar studies be replicated across two or more provinces as well as the nation. Further, the study did not explore the performance of preservice teachers who were exposed to small class sizes but lacked the desired support of subject mentors, vis-à-vis those who had the support of subject mentors, but were exposed to large class sizes. Thus, studies can be conducted in this direction to know which is more valuable: smaller class sizes or the support of subject mentors. Lastly, data on the views of the learners were not collected; hence, in replicating similar studies, the opinions of learners can be sought as well.

\section{Acknowledgement}

The researcher would like to acknowledge and appreciate the Department of Social Science Education, Faculty of Education, and Research Office of the University of Zululand, KwaDlangezwa, KwaZulu-Natal, South Africa, as well as the Department of Education Leadership and Management, University of Johannesburg, Auckland Park, Gauteng, Johannesburg, South Africa for supporting this research in various ways.

\section{REFERENCES}

Aoumeur, Hayat. 2017. "The Impact of Class Size on Teaching and Learning English as a Foreign Language: The Case of the Department of English at Abdelhamid Ibn Badis University." Arab World English Journal $8 \quad$ (2): $349-361$. https://dx.doi.org/10.24093/awej/vol8no2.25.

Baker, Jean A., Sycarah Grant, and Larissa Morlock. 2008. "The Teacher-Student Relationship as a Developmental Context for Children with Internalizing or Externalizing Behavior Problems." School Psychology Quarterly $23 \quad$ (1): 3-15. https://psycnet.apa.org/doi/10.1037/1045-3830.23.1.3.

Baumeister, Roy F., Jennifer D. Campbell, Joachim I. Krueger, and Kathleen D. Vohs. 2003. "Does High Self-Esteem Cause Better Performance, Interpersonal Success, Happiness, or Healthier Lifestyles?" Psychological Science in the Public Interest 4 (1): 1-44. https://doi.org/10.1111/1529-1006.01431.

Blatchford, Peter, Viv Moriarty, Suzaane Edmonds, and Clare Martin. 2002. "Relationships between Class Size and Teaching: A Multimethod Analysis of English Infant Schools." American Educational Research Journal 39 (1): 101-132. https://www.jstor.org/stable/3202473.

Bruno, U. D. O., and Joyce Njoku. 2014. "The Role of the Teacher in Improving Students Self Esteem." International Journal of Academic Research in Progressive Education and Development 3 (1): 47-57. https://doi.org/10.6007/IJARPED/v3-i1/615.

Creswell, John. 2014. Research Design: Qualitative, Quantitative and Mixed Methods Approaches, 4th ed. Thousand Oaks, CA, Sage.

Du Plooy-Cilliers, Franzel, Corne Davis, and Rose-Marie Bezuidenhout, eds. 2014. Research Matters. Pretoria, South Africa: JUTA. 
Herbert-Smith, Kate. 2018. "6 Ways to Boost Your Confidence as a Teacher." Accessed August 30, 2019. https://blog.irisconnect.com/uk/community/blog/5-ways-to-boost-yourconfidence-as-a-teacher-1.

Hutt, Ethan, and Tang, Aaron. 2013. “The New Education Malpractice Litigation." Social Science Research Network 99 (3): 419-491. https://law.stanford.edu/publications/thenew-education-malpractice-litigation.

Jan, Farooq. 2015. "The Factors Affecting Teachers' Self-Esteem in the Higher Educational Institutions." Research on Humanities and Social Sciences 5 (9): 132-137. https://iiste.org/Journals/index.php/JAAS/article/view/22748.

Kumar, Ranjit. 2014. Research Methodology: A Step-by-Step Guide for Beginners. Thousand Oaks, CA: SAGE Publications.

Omodan, Bunmi Isaiah, and Bekithemba Dube. 2020. "Towards De-Colonial Agitations in University Classrooms: The Quest for Afrocentric Pedagogy." International Journal of Learning, Teaching and Educational Research 19 (4): 14-28. https://doi.org/10.26803/ijlter.19.4.2.

Osborne, Molly. 2018. “Class Size Debate: What Do Teachers Think?” Accessed June 24, 2020. https://nccppr.org/class-size-debate-teachers-think/.

Sadler, Ian. 2013. "The Role of Self-Confidence in Learning to Teach in Higher Education." Innovations in Education and Teaching International 50 (2): 157-166. https://doi.org/10.1080/14703297.2012.760777.

Shore, Ken. 2016. "The Student with Low Self-Esteem." Accessed July 27, 2019. http://www.educationworld.com.

Sibiya, Iris Nondumiso, Bongani Thulani Gamede, and Chinaza Uleanya. 2019. "Classroom Management Challenges Experienced by Female Educators in Rural Secondary Schools in South Africa." Gender and Behaviour 17 (2): 12894-12909. https://hdl.handle.net/10520/EJC-16eb3ec6b4.

Uleanya, Chinaza, and Bongani Thulani Gamede. 2018. "Correlates of Pedagogic Malpractices." The Independent Journal of Teaching and Learning 13 (2): 36-52. https://hdl.handle.net/10520/EJC-122245b2ba.

Uleanya, Chinaza, Yasmin Rugbeer, and Sunday Olawale Olaniran. 2019. "Decolonization of Education: Exploring a New Praxis for Sustainable Development." African Identities 17 (2): 94-107. https://doi.org/10.1080/14725843.2019.1659752.

Valazza, Gerardo. 2019. "Professional Development: Teacher Development and Confidence." Accessed August 30, 2019. http://www.onestopenglish.com/methodology/teachingarticles/professional development/professional-development-teacher-development-andconfidence/146473.article.

Yelkpieri, Daniel, Matthew Namale, Kweku Esia-Donkoh, and Eric Ofosu-Dwamena. 2012. "Effects of Large Class Size on Effective Teaching and Learning at the Winneba Campus of the UEW (University of Education, Winneba), Ghana." US-China Education Review A 3:319-332. https://eric.ed.gov/?id=ED532900.

\section{ABOUT THE AUTHOR}

Chinaza Uleanya: Postdoctoral Fellow, Department of Business Management, University of South Africa, Gauteng, South Africa 
The International Journal of Interdisciplinary

Educational Studies is one of four thematically focused

journals that support the Interdisciplinary Social

Sciences Research Network. The Research Network is

comprised of a journal collection, book imprint,

conference, and online community.

The journal presents studies that exemplify the disciplinary and interdisciplinary practices of the social sciences. As well as articles of a traditional scholarly type, this journal invites case studies that take the form of presentations of practice-including documentation of socially engaged practices and exegeses analyzing the effects of those practices.

The International Journal of Interdisciplinary

Educational Studies is a peer-reviewed, scholarly journal. 